\title{
PENGARUH STRATEGI PEMBELAJARAN DAN SELF- EFFICACY TERHADAP PENGETAHUAN SISWA TENTANG KONSEP DASAR EKOLOGI
}

\author{
Semuel Sanda Patampang \\ Universitas Negeri Jakarta \\ Samuel_sapat@yahoo.com
}

\begin{abstract}
The purpose of this research is to know the effect of instructional strategy and selfefficacy of the students' knowledge about basic concepts of ecology. This research uses an experimental method to design treatment by level $2 \times 2$ on the class $X$ of the Senior High School 3 Palu. Sample of 48 students, selected using multistage random sampling, and are divided into groups. The results: (1) Knowledge of the basic concepts of ecology in students group taught instructional strategy inductive is higher, than that taught instructional strategy deductive; (2) For a students group who have high self-efficacy, to the knowledge of the basic concepts of ecology, taught instructional strategy inductive is higher, than that taught instructional strategy deductive; (3) For a students group who have low self-efficacy, to the knowledge of basic concepts of ecology, taught instructional strategy deductive is higher, than that taught instructional strategy inductive; and (4) There is an interaction effect between instructional strategy and self-efficacy of the students' knowledge about basic concepts of ecology. From this research, it was found that the students group who have high self-efficacy, to the knowledge of the basic concepts of ecology better taught instructional strategy inductive, while in the students group have low self-efficacy better taught instructional strategy deductive.
\end{abstract}

Keywords: Instructional Strategy, Self-Efficacy, Knowledge basic consepts of ecology 


\section{PENDAHULUAN}

Ekologi telah menjadi salah satu cabang disiplin ilmu pengetahuan tersendiri sejak 1900 yang memfokuskan materi kajiannya pada aspekaspek yang ada kaitannya dengan hubungan timbal balik antara organisme dengan lingkungannya. Odum dan Barrett (2005:2) menyatakan bahwa ekologi ilmu yang mempelajari organisme di lingkungannya. Biasanya ekologi didefinisikan sebagai ilmu pengetahuan yang mempelajari hubungan dari organisme atau kelompok organisme di lingkungannya, atau ilmu pengetahuan yang mempelajari hubungan timbal balik antara makhluk hidup dengan lingkungannya. Hubungan timbal balik tersebut terjadi antar komponen yaitu, produsen, konsumen, dan pengurai." Demikian pula Odum (1971:3) menyatakan, bahwa ekologi merupakan pengkajian organismeorganisme atau kelompok-kelompok organisme terhadap lingkungannya, atau ilmu hubungan timbal balik antara organisme-organisme hidup dan lingkungannya. Sehingga, masalah-masalah ekologi/ lingkungan yang terjadi terkait erat dengan aktivitas organisme hidup terutama manusia yang mengakibatkan rusaknya lingkungan.

Jika saat dunia mengalami masalah lingkungan, maka ekologi merupakan salah satu cabang ilmu yang mendasarinya. Saat ini ekologi bagi semua orang wajib mengetahui dan memahaminya, karena prinsipprinsip ekologi dapat menerangkan dan memberikan ilham dalam mencari jalan untuk mencapai kehidupan yang lebih layak. Ekologi sebagai ilmu pengetahuan memiliki konsep-konsep dasar. Odum (1971:3) menyatakan bahwa konsep dasar ekologi terdiri atas konsep tentang individu, habitat, 
populasi, komunitas, ekosistem, konsep energi, dan daur biogeokimia. Selanjutnya Odum (1979:3) mengemukakan bahwa, lingkungan hidup didasarkan pada beberapa konsep dasar ekologi, seperti konsep: biotik, abiotik, ekosistem, produktivitas, biomasa, hukum thermodinamika I dan hukum thermoddinamika II, siklus biogeokimiawi dan konsep faktor pembatas. Dalam komunitas ada konsep biodiversitas, pada populasi ada konsep "carrying capacity", dan pada spesies ada konsep distribusi dan interaksi serta konsep suksesi dan klimaks. Jadi pengetahuan tentang ekologi semakin diperlukan dalam kehidupan manusia masa kini karena dengan memahami materi ekologi, manusia dapat mencegah dan memecahkan permasalahan lingkungan yang sedang dihadapinya.

Menurut Irwan (2010:6) menyatakan bahwa ekologi merupakan salah satu cabang biologi yaitu ilmu pengetahuan tentang hubungan antara organisme dan lingkungannya. Atau ilmu yang mempelajari pengaruh faktor lingkungan terhadap jasad hidup. Juga dinyatakan bahwa ekologi adalah suatu ilmu yang mencoba mempelajari hubungan antara tumbuhan, binatang dan manusia dengan lingkungannya di mana mereka hidup, bagaimana kehidupannya dan mengapa mereka ada di situ. Odum dan Barrett (2005:4) menyatakan bahwa peningkatan perhatian publik memiliki efek mendalam pada ekologi teoretis. Sebelum tahun 1970-an ekologi dipandang sebagian besar sebagai sub disiplin biologi. Ekologi dikelola di departemen biologi, dan kursus ekologi pada umumnya hanya ditemukan dalam kurikulum ilmu biologi. Meskipun ekologi tetap berakar kuat dalam biologi, telah muncul dari biologi sebagai dasar yang baru, disiplin integratif 
yang menghubungkan fisik dan proses biologis dan bentuk jembatan antara ilmu alam dan ilmu-ilmu sosial.

Namun materi ekologi dalam kurikulum Sekolah Menengah Atas (SMA) seperti di SMA Negeri 3 Palu, masih terintegrasi dalam beberapa mata pelajaran seperti; biologi, kimia, geografi, fisika, sosiologi, dan lain-lain. Sejak tahun 2002 setelah terjadi musibah kebakaran SMA Negeri 3 Palu, maka kepala sekolah membuat kebijakan yang didukung oleh semua warga sekolah untuk mewujudkan sekolah berwawasan lingkungan dengan mengintegrasikan materi Pendidikan Lingkungan Hidup (PLH) ke dalam pembelajaran secara kurikuler dan ekstrakulikuler antara lain melalui: (a) Pendekatan dalam pelaksanaan Pembelajaran PLH secara terpadu, (b) Pengitegrasian PLH pada kegiatan pembelajaran, dan (c) mencadangkan budaya lingkungan. Untuk mata pelajaran muatan lokal (mulok) dipilih Pendidikan Lingkungan Hidup dengan penekanan pada materi tanaman hias yang langsung diwujudkan dalam lingkungan sekolah. Kebijakan tersebut dimuatlah dalam visi sekolah: "Unggul dalam IPTEK, Mantap dalam IMTAQ, dan Peduli Lingkungan". Jadi dalam mata pelajaran biologi materi konsep dasar ekologi dipelajari siswa di kelas $\mathrm{X}$ dan menjadi keharusan bagi siswa untuk memahami dan menguasainya. Siswa sebagai generasi masa depan yang akan banyak diperhadapkan pada permaslahan lingkungan, apabila mereka telah memahami konsep-konsep ekologi, maka dengan sendirinya dapat ikut serta dalam upaya pencegahan dan pemecahan permasalahan lingkungan. UNESCO (1977:355) menyatakan bahwa seorang siswa yang mempunyai kemampuan untuk memecahkan masalah dalam pembelajaran, 
maka akan mempunyai prestasi belajar yang baik dalam hasil belajar, implikasinya dalam kehidupan di masyarakat, siswa yang bersakutan akan berperan dalam proses pemecahan masalah pada kehidupan sehari-hari.

Untuk itu dalam proses pembelajaran materi ekologi di sekolah salah satu komponen pembelajaran diperlukan adalah strategi pembelajaran yang efektif memudahkan siswa mengetahui dan memahami materi ekologi itu. Dalam proses pembelajaran Konsep dasar ekologi dibutuhkan strategi pembelajaran yang merupakan siasat atau taktik dalam upaya meningkatkan pengetahuan siswa tentang materi pelajaran itu. Bruce (2000:135) mengatakan bahwa secara umum strategi dapat diartikan sebagai suatu garis besar haluan bertindak untuk mencapai sasaran yang telah ditetapkan. Pembelajaran menurut Gagne dan Briggs (1979:19) adalah suatu set peristiwa yang mempengaruhi siswa sehingga terjadi proses belajar. Suatu set peristiwa itu dapat dilakukan oleh pengajar sehingga disebut pengajaran, bisa oleh siswa sendiri dengan menggunakan buku, gambar, program televisi atau kombinasi berbagai media. Kedua kegiatan di atas haruslah terencana secara sistematik untuk dapat disebut kegiatan pembelajaran. Sehingga pengajaran merupakan salah satu kegiatan pembelajaran.

Selama dasawarsa yang lalu hingga saat ini masih ada sebagian guru-guru di sekolah menggunakan strategi pembelajaran konvensional yang kurang memberikan kesempatan pada siswa aktif dalam proses pembelajaran, sehingga menyebabkan siswa masih kurang memahami materi pelajaran. Seharusnya strategi pembelajaran konstruktif yang 
digunakan karena dalam proses pembelajaran lebih banyak melibatkan siswa aktif, kreatif, dan inovatif.

Namun masih menjadi kenyataan di lapangan seperti di SMA negeri 3 Palu, bahwa masih banyak guru yang belum mengaplikasikan pembelajaran yang berorientasi konstruktivisme, karena masih terbiasa dengan pola teacher centered, guru belum mengembangkan kemampuan keterampilan proses bagi siswa, kemampuan berpikir masih dalam kategori rendah, misalnya menghafal konsep-konsep dari texbook yang diberikan guru. Guru belum memberdayakan potensi siswa sebagaimana yang diamanatkan Undang-Undang Sistem Pendidikan Nasional No. 20 tahun 2003. Masih rendahnya proses pembelajaran dapat dilihat dari hasil pembelajaran siswa yang masih rendah di mana ada sebagian siswa yang mengikuti remedial karena skor yang diperoleh belum memenuhi kriteria ketuntasan minimal yang ditetapkan di sekolah. Maka dibutuhkan strategi pembelajaran yang memungkinkan siswa dapat memahami materi pelajaran yang disajikan guru dalam proses pembelajaran di kelas termasuk materi ekologi. Beberapa strategi pembelajaran yang potensial dapat dilakukan guru dalam proses pembelajaran seperti jenis strategi pembelajaran induktif yang masih jarang digunakan guru dalam proses pembelajaran. Strategi pembelajaran ditinjau dari cara menyajikan materi dapat dibagi dua, yaitu: (a) strategi pembelajaran deduktif; dan (b) strategi pembelajaran induktif. Strategi pembelajaran deduktif berupaya menyajikan materi secara umum ke khusus, atau dimulai dari hal-hal yang abstrak menuju ke hal-hal konkrit. Sedangkan strategi induktif menyajikan materi yang konkrit selanjutnya 
diarahkan pada materi yang kompleks, atau dimulai dari hal khusus menuju ke hal umum. Juga guru belum banyak memberi perhatian pada aspek personality yang dimiliki siswa seperti self efficacy. Menurut Lennon (2010:92) menyatakan bahwa self-efficacy adalah sebuah konsep yang diambil dari teori person yang menyatakan bahwa pencapaian manusia bergantung pada hubungan timbal balik antara prilaku, individu, dan kondisi lingkungan. Self-efficacy merupakan salah satu faktor penentu keberhasilan dalam performansi yang akan datang. Tingginya Self-efficacy akan memotivasi individu secara kognitif untuk bertindak lebih persisten dan terarah, terutama apabila tujuan yang hendak dicapai merupakan tujuan yang jelas. Bandura (1997:3) mengatakan bahwa self-efficacy sebagai keyakinan seseorang akan kemampuannya untuk mengorganisasi dan melaksanakan rangkaian tindakan yang dibutuhkan untuk menghasilkan pencapaian tujuan.

Untuk penelitian eksperimen ini sebagai variabel perlakuan adalah strategi pembelajaran $(A)$ terdiri dari strategi pembelajaran induktif $\left(A_{1}\right)$ diperlakukan pada kelas eksperimen dan strategi pembelajaran deduktif $\left(A_{2}\right)$ diperlakukan pada kelas kontrol. Kemudian variabel. atribut dipilih salah satu aspek personality siswa yaitu self-efficacy (B) yang masih jarang menjadi perhatian guru, dan sebagai variabel terikat adalah pengetahuan siswa tentang konsep dasar ekologi $(\mathrm{Y})$.

Secara umum penelitian ini bertujuan untuk mengetahui pengaruh strategi pembelajaran (induktif vs deduktif) dan self-efficacy terhadap 
pengetahuan siswa tentang konsep dasar ekologi. Selanjutnya secara khusus tujuan penelitian ini untuk mengetahui:

1. Pengaruh strategi pembelajaran induktif dan strategi pembelajaran deduktif yang berbeda, terhadap pengetahuan siswa tentang konsep dasar ekologi.

2. Pengaruh strategi pembelajaran induktif dan strategi pembelajaran deduktif yang berbeda, bagi kelompok siswa yang memiliki self-efficacy tinggi terhadap pengetahuan tentang konsep dasar ekologi.

3. Pengaruh strategi pembelajaran induktif dan strategi pembelajaran deduktif yang berbeda, bagi kelompok siswa yang memiliki self-efficacy rendah, terhadap pengetahuan tentang konsep dasar ekologi.

4. Pengaruh interaksi strategi pembelajaran dan self-efficacy terhadap pengetahuan siswa tentang konsep dasar ekologi.

\section{METODOLOGI}

Penelitian ini dilaksanakan pada siswa SMA Negeri 3 Palu di Kota Palu Propinsi Sulawesi Tengah sejak Januari sampai dengan Juni 2013. Metode penelitian digunakan adalah metode eksperimen. Variabel terikat adalah pengetahuan siswa tentang konsep dasar ekologi $(\mathrm{Y})$, variabel bebas perlakuan strategi pembelajaran $(A)$ terdiri dari trategi pembelajaran induktif $\left(A_{1}\right)$ vs strategi pembelajaran deduktif $\left(A_{2}\right)$, dan variabel atribut self-efficacy (B) terdiri dari self-efficacy tinggi $\left(B_{1}\right)$ dan self-efficacy rendah $\left(B_{2}\right)$. Rancangan eksperimen berdasarkan desain yang dikemukakan Borg dan Gall (1983:683) yaitu Desain Treatment by Level 2 X 2. Desain eksperimen yang telah dimodifikasi nampak pada gambar 1 di bawah ini. 


\begin{tabular}{|c|c|c|c|}
\hline \multirow{2}{*}{\multicolumn{2}{|c|}{$\begin{array}{ll}\text { Variabel } & \begin{array}{c}\text { Variabel } \\
\text { Atribut }\end{array}\end{array}$}} & \multicolumn{2}{|c|}{ Strategi Pembelajaran (A) } \\
\hline & & $\begin{array}{c}\text { Induktif } \\
\left(A_{1}\right)\end{array}$ & $\begin{array}{c}\text { Dedukti } \\
\left(A_{2}\right)\end{array}$ \\
\hline \multirow[b]{2}{*}{$\begin{array}{l}\text { Self- } \\
\text { Efficacy (B) }\end{array}$} & \begin{tabular}{|c|} 
Tinggi \\
$\left(B_{1}\right)$
\end{tabular} & $A_{1} B_{1}$ & $\mathrm{~A}_{2} \mathrm{~B}_{1}$ \\
\hline & $\begin{array}{c}\text { Rendah } \\
\left(\mathrm{B}_{2}\right)\end{array}$ & $A_{1} B_{2}$ & $A_{2} B_{2}$ \\
\hline
\end{tabular}

Gambar 1. Desain Eksperimen

Pengambilan sampel dilakukan dengan teknik multi-stage random sampling, dengan tahapan sebagai berikut:

Tahapan pertama, peneliti memilih secara random di antara kelas $\mathrm{X}$ yang berjumlah 10 kelas untuk menetapkan kelas eksperimen (kelas $X \mathrm{D}$ ) dan kelas kontrol (kelas X C). Tahapan kedua, dari penetapan sampel random tersebut, terpilih kelas X D sebagai kelas eksperimen atau kelas strategi pembelajaran induktif $\left(A_{1}\right)$ dan kelas $X C$ sebagai kels kontrol atau kelas strategi pembelajaran deduktif $\left(A_{2}\right)$. Tahapan ketiga, terhadap seluruh siswa kelas eksperimen 35 siswa dan juga kelas kontrol 35 siswa, dan pada kedua kelas ini dilakukan pengukuran variabel atribut self-efficacy yang berbentuk kuesioner, kemudian hasil atau skor masing-masing siswa diurutkan, baik pada kelas eksperimen maupun pada kelas kontrol. Tahapan keempat, untuk penetapan besarnya sampel penelitian pada masing-masing kelas penelitian, dilakukan pengambilan $33 \%$ siswa untuk setiap kelompok (Nitko, 1996:310). Jadi jumlah sampel pada skor sel-efficacy tinggi 12 siswa dan skor self-efficacy rendah 12 siswa, sehingga untuk kelas strategi pembelajaran induktif 24 siswa, dan pada skor self-efficacy tinggi 12 siswa dan skor self-efficacy rendah 12 siswa, sehingga untuk kelas strategi 
pembelajaran deduktif 24 siswa. Jadi total sampel penelitian ini adalah 48 siswa.

Pengumpulan data menggunakan 36 butir Instrumen kuesioner self-efficacy yang telah divaliditas dengan rumus Korelasi Pearson Product Moment dan reliabel dengan rumus Alfa-Cronbach, untuk menentukan self-efficacy tinggi dan self-efficacy rendah. Juga 61 butir soal yang telah divaliditas dengan rumus Indeks Korelasi Point Biserial dan reliabel dengan rumus K-R 20, untuk memperoleh hasil belajar sebagai pengetahuan siswa tentang konsep dasar ekologi. Tehknik analisis data meliputi analisis statistik deskriptif dengan penyajian data dalam bentuk tabel distribusi frekuensi, rerata, modus, median, simpangan baku, varians dan histogram. Sedangkan analisis statistik inferensial untuk uji hipotesis penelitian menggunakan rumus ANAVA Dua Jalur membandingkan Fhitung dengan Ftabel pada setiap faktor perlakuan (A dan B), dan interaksi antar faktor (A X B). Karena ada interaksi antara A X B, maka uji dilanjutkan dengan uji Tuckey untuk mengetahui kebermaknaan interaksi. Sebelum dilakukan pengujian hipotesis, kelompok-kelompok data diuji normalitasnya dengan uji Liliefors ternyata semua kelompok data berdistrbusi normal, dan uji homogenitas dengan uji Bartlett ternyata semua data bersifat homogen.

\section{HASIL DAN PEMBAHASAN}

Pengujian persyaratan analisis: uji nomalitas dengan uji Lilliefors dan uji homogenitas dengan uji Bartlett. Hasil uji normalitas data skor pengetahuan siswa tentang konsep dasar ekologi untuk masing-masing kelompok 
perlakuan, secara keseluruhan menunjukkan data berdistribusi normal. Pengujian homogenitas data skor pengetahuan siswa tentang konsep dasar ekologi pada kelompok data $\mathrm{n}=24$ dan sub kelompok $\mathrm{n}=12$, secara umum menunjukkan varians yang sama atau kelompok data bersifat homogen.

Setelah persyaratan pengujian analisis, maka pengujian hipotesis dilakukan dengan menggunakan analisis varians (ANAVA) dua jalur pada taraf signifikan $5 \%(\alpha=0.05)$. Adapun ringkasan hasil perhitungan analisis data, dapat dilihat pada Tabel 2 di bawah ini.

Tabel 1. Ringkasan Analisis Data Hasil Tes Pengetahuan Siswa tentang Konsep Dasar Ekologi dengan ANAVA Dua Jalur

\begin{tabular}{|c|c|c|c|c|c|c|}
\hline \multirow[b]{2}{*}{ Sumber Varians } & \multirow[b]{2}{*}{ dk } & \multirow[b]{2}{*}{ JK } & \multirow[b]{2}{*}{ RJK } & \multirow[b]{2}{*}{ Fhitung } & \multicolumn{2}{|c|}{ Ftabel } \\
\hline & & & & & 0,05 & 0.01 \\
\hline $\begin{array}{l}\text { Strategi Pembela- } \\
\text { jaran }(A)=\text { Kolom }\end{array}$ & 1 & 76,021 & 76,021 & $4,72^{*}$ & \multirow{3}{*}{4,06} & \multirow{3}{*}{7,24} \\
\hline $\begin{array}{l}\text { Self Eficacy }(\mathrm{B})= \\
\text { Baris }\end{array}$ & 1 & 67,688 & 67,688 & $4,20^{*}$ & & \\
\hline Interaksi AXB & 1 & 172,519 & 172,519 & $10,70^{* *}$ & & \\
\hline Antar Kelompok & 3 & 286,228 & 95,409 & $5,92^{\star \star}$ & \multirow{3}{*}{2,82} & \multirow{3}{*}{4,26} \\
\hline Dalam Kelompok & 44 & 709,251 & 16,119 & & & \\
\hline Jumlah & 47 & 995,479 & & & & \\
\hline
\end{tabular}

- $\mathrm{P}<.05 ;{ }^{* *} \mathrm{p}<.01$

\section{Keterangan:}

$\mathrm{dk} \quad=$ derajat kebebasan

$\mathrm{JK} \quad=$ Jumlah Kuadrat

RJK = Rerata Jumlah Kuadrat

Berdasarkan data pada Tabel 2 di atas, dapat dijelaskan hasil uji hipotesis penelitian: Hipotesis 1, Secara keseluruhan, pengetahuan tentang konsep dasar ekologi pada kelompok siswa diajar dengan strategi pembelajaran induktif lebih tinggi, jika dibandingkan yang diajar dengan strategi pembelajaran deduktif (Main Effect). Hasil perhitungan ANAVA dua jalur 
diperoleh $F_{\text {hit }} 4,72>F_{\text {tab }}(0,05 ; 1 ; 48) 4,06$. Fakta ini berarti terdapat perbedaan pengaruh antara kelompok siswa yang diajar strategi pembelajaran induktif dan kelompok siswa yang diajar strategi pembelajaran deduktif terhadap pengetahuan tentang konsep dasar ekologi. Hipotesis 2, Bagi kelompok siswa yang memiliki self-efficacy tinggi, untuk pengetahuan tentang konsep dasar ekologi yang diajar dengan strategi pembelajaran induktif lebih tinggi, jika dibandingkan yang diajar dengan strategi pembelajaran deduktif (Simple Effect). Hasil pengujian uji Tuckey diperoleh Qhit 4,961 > Qtab ( $\alpha=0,05 ; \mathrm{db} 1=4$; db2 $=10) 4,26$. Fakta ini berarti pengetahuan tentang konsep dasar ekologi pada kelompok siswa yang memiliki self-efficacy tinggi, diajar strategi pembelajaran induktif lebih tinggi, dibandingkan yang diajar strategi pembelajaran deduktif. Jadi dapat dikatakan terdapat perbedaan pengaruh antara kelompok siswa yang memilki self-efficacy tinggi, diajar strategi pembelajaran induktif dan yang diajar strategi pembelajaran deduktif terhadap pengetahuan tentang konsep dasar ekologi. Hipotesis 3, Bagi kelompok siswa yang memiliki self-efficacy rendah, untuk pengetahuan tentang konsep dasar ekologi yang diajar dengan strategi pembelajaran deduktif lebih tinggi, jika dibandingkan yang diajar dengan strategi pembelajaran induktif (Simple Effect). Hasil pengujian uji Tuckey diperoleh

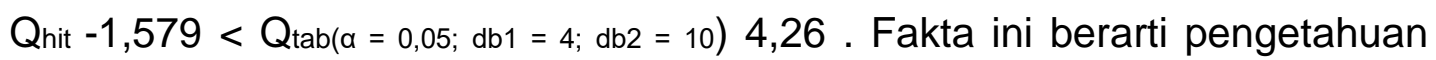
tentang konsep dasar ekologi pada kelompok siswa yang memiliki selfefficacy rendah, diajar strategi pembelajaran deduktif lebih tinggi, dibandingkan yang diajar strategi pembelajaran induktif. Jadi dapat dikatakan terdapat perbedaan pengaruh antara kelompok siswa memiliki 
self-efficacy rendah, diajar strategi pembelajaran deduktif dan yang diajar strategi pembelajaran induktif terhadap pengetahuan tentang konsep dasar ekologi. Hipotesis 4, Terdapat pengaruh interaksi antara strategi pembelajaran dan self-efficacy terhadap pengetahuan siswa tentang konsep dasar ekologi (interaction effect). Hasil pengujian ANAVA dua jalur diperoleh $F_{\text {hit }} 10,70>F_{\text {tab }}(0,05 ; 1 ; 47) 4,06$. Fakta ini berarti terdapat pengaruh interaksi antara strategi pembelajaran dan self-efficacy terhadap pengetahuan siswa tentang konsep dasar ekologi. Hal ini dapat divisualisasikan dalam bentuk diagram pada gambar 2 di bawah ini.

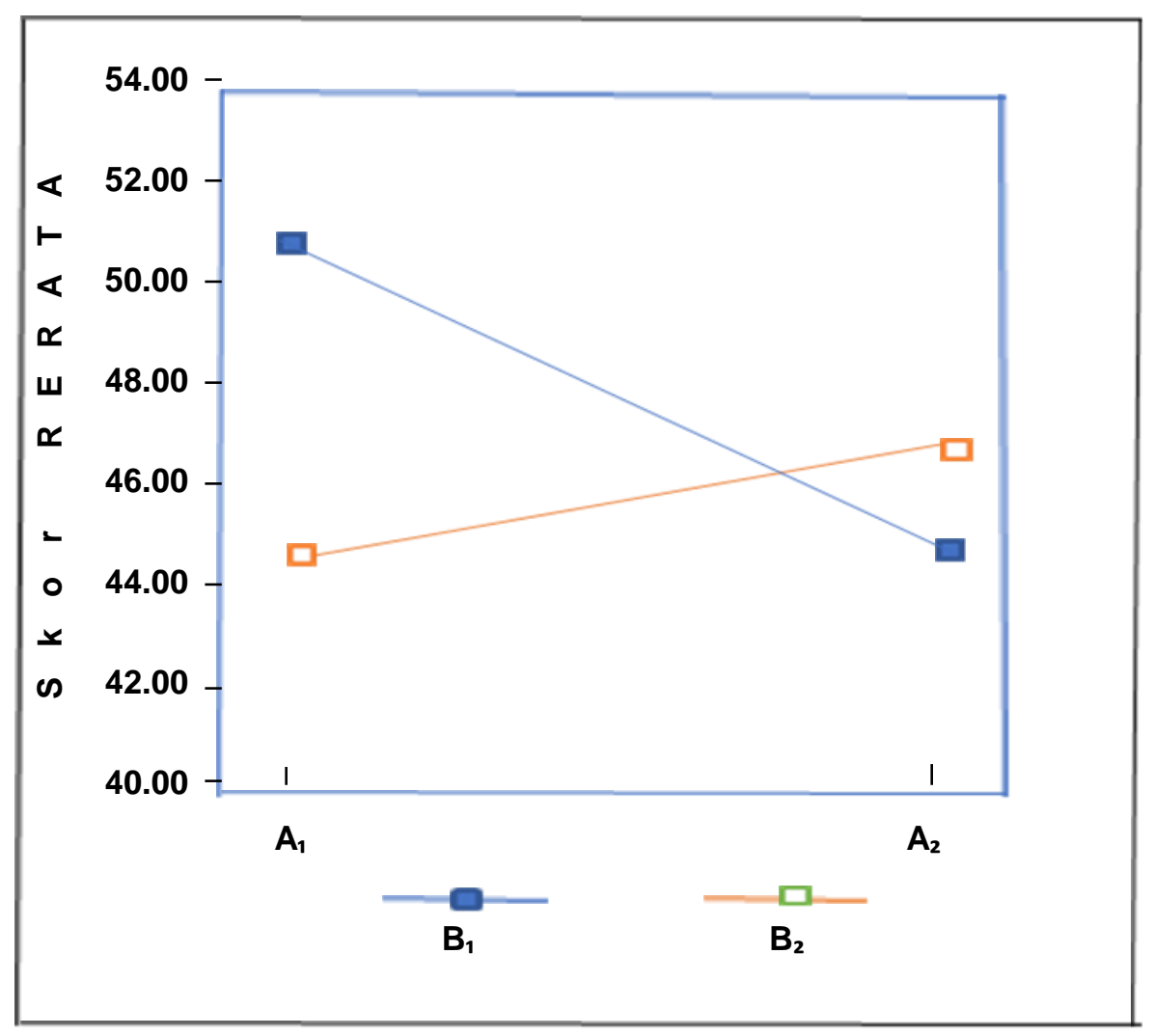

Gambar2. DiagramPengaruh Interaksi antara Strategi Pembelajaran dan Self-Efficacy Siswa Terhadap Pengetahuan tentang Konsep Dasar Ekologi 
Diagram pada gambar 2 di atas menunjukkan bahwa terdapat pengaruh interaksi strategi pembelajaran dan self-efficacy siswa terhadap pengetahuan siswa tentang konsep dasar ekologi. Oleh karena itu dilakukan uji lanjut uji Tuckey untuk mengetahui kebermaknaan interaksi. Uji Tuckey digunakan untuk mengetahui tingkat kebermaknaan yang berhubungan dengan faktor B terhadap faktor A. Notasi yang diuji adalah pasangan sel $A_{1} B_{1}-A_{2} B_{1}$ dan $A_{1} B_{2}-A_{2} B_{2}$. Ringkasan analisis data dengan uji Tuckey dapat dilihat pada Tabel 3 berikut ini.

Tabel 2. Ringkasan Hasil Uji Tuckey

\begin{tabular}{|c|c|c|c|c|c|}
\hline No. & $\begin{array}{c}\text { Sumber } \\
\text { Varians }\end{array}$ & Rata-Rata & Qhitung & $\begin{array}{c}\text { Qtabel } \\
(\alpha=0,05)\end{array}$ & Kesimpulan \\
\hline 1. & $A_{1} B_{1}><A_{2} B_{1}$ & $50,667-44,917$ & 4,961 & 4,26 & Signifikan \\
\hline 2. & $A_{1} B_{2}><A_{2} B_{2}$ & $44,50-46,333$ & $-1,579$ & 4,26 & Non signifikan \\
\hline
\end{tabular}

\section{Keterangan:}

1. $A_{1} B_{1}=$ Strategi Pembelajaran Induktif dengan Self-Efficacy Tinggi

2. $A_{2} B_{1}=$ Strategi Pembelajaran Deduktif dengan Self-Efficacy Tinggi

3. $A_{1} B_{2}=$ Srategi Pembelajaran Induktif dengan Self-Efficacy Rendah

4. $A_{2} B_{2}=$ Strategi Pembelajaran Deduktif dengan Sel-Efficacy Rendah.

Hasil ringkasan pengujian uji Tuckey yang nampak pada Tabel 3. di atas, dapat menjelaskan tentang pengujian hipotesis kedua dan ketiga yang dapat memberikan gambaran tentang side effect dari penelitian ini. Karena dengan melakukan uji Tuckey untuk faktor strategi pembelajaran induktif dengan self-efficacy Tinggi dibandingkan dengan faktor strategi pembelajaran deduktif dengan self-efficacy tinggi $\left(\mathrm{A}_{1} \mathrm{~B}_{1}><\mathrm{A}_{2} \mathrm{~B}_{1}\right)$, maka didapatkan harga 
Qhit 4,961 > Qtab 4,26. Fakta ini berarti pengetahuan tentang konsep dasar ekologi pada kelompok siswa yang memiliki self-efficacy tinggi, diajar strategi pembelajaran induktif lebih tinggi, dibandingkan yang diajar strategi pembelajaran deduktif (pengujian hipotesis kedua). Selanjutnya pengujian uji Tuckey untuk faktor strategi pembelajaran induktif dengan self-efficacy rendah, dibandingkan dengan faktor strategi pembelajaran deduktif dengan self-efficacy rendah $\left(\mathrm{A}_{1} \mathrm{~B}_{2}><\mathrm{A}_{2} \mathrm{~B}_{2}\right)$, maka didapatkan $\mathrm{Q}_{\text {hit }}-1,579<\mathrm{Qtab}_{(\alpha}=$ $0,05 ; \mathrm{db} 1=4 ; \mathrm{db} 2=10) \quad 4,26$ (pengujian hipotesis ketiga). Fakta ini berarti pengetahuan tentang konsep dasar ekologi pada kelompok siswa yang memiliki self-efficacy rendah, diajar strategi pembelajaran deduktif lebih tinggi, dibandingkan yang diajar strategi pembelajaran induktif.

Hasil pengujian pada keempat hipotesis yang telah dijelaskan pada bagian di atas, maka semua hipotesis telah teruji, yaitu: Hipotesis 1, Secara keseluruhan, pengetahuan tentang konsep dasar ekologi pada kelompok siswa yang diajar dengan strategi pembelajaran induktif lebih tinggi, jika dibandingkan yang diajar dengan strategi pembelajaran deduktif. Hasil penelitian ( $\left.F_{\text {hit. }} 4,72>F_{\text {tab. }(0,05 ; 1 ; 48)} 4,06\right)$ bahwa pada kelompok siswa yang diajar strategi pembelajaran induktif lebih baik dari pada yang diajar strategi pembelajaran deduktif terhadap pengetahuan tentang konsep dasar ekologi. Artinya pengetahuan siswa tentang konsep dasar ekologi dapat dipengaruhi penerapan strategi pembelajaran yang berbeda dalam proses pembelajaran. Hasil penelitian juga menunjukkan bahwa kelompok siswa yang mengikuti penerapan strategi pembelajaran induktif, memperoleh skor rata-rata 47,583 berarti setiap siswa yang mengikuti proses pembelajaran 
dengan penerapan strategi pembelajaran induktif dapat mengetahui materi konsep dasar ekologi sebesar 47,583 (78\%) dari skor maksimum materi pembelajaran konaep dasar ekologi sebesar 61. Sedangkan kelompok siswa dengan penerapan strategi pembelajaran deduktif memperoleh skor rata-rata 45,625 berarti setiap siswa yang mengikuti proses pembelajaran dengan penerapan strategi pembelajaran deduktif dapat mengetahui materi konsep dasar ekologi sebesar 45,625 (74,80\%) dari skor maksimum materi pembelajaran konsep dasar ekologi sebesar 61. Kelompok siswa yang diajar dengan strategi pembelajaran induktif dapat mengetahui tentang konsep dasar ekologi lebih tinggi, karena dalam proses pembelajaran ini siswa lebih aktif dilibatkan dalam situasi pembahasan materi pelajaran dan secara perlahan-lahan dihadapkan pada materi yang sukar dan kompleks. Dengan demikian siswa dibiasakan mengembangkan ketrampilan berpikir tingkat tinggi, kreatif dan kritis. Sedangkan dalam proses pembelajaran dengan penerapan strategi pembelajaran deduktif, siswa kurang aktif karena lebih diarahkan pada penerimaan konsep dan prinsip-prinsip materi pelajaran yang sudah ada. Dalam hal ini siswa tidak dapat berkembang dengan situasi berpikir tingkat tinggi, kreatif dan kritis. Temuan penelitian tersebut diperkuat dengan pendapat Hilda Taba (dalam Anon, Oktober 2010) yang merancang dan mengembang model berfikir induktif dengan tujuan untuk mendorong para pelajar menemukan dan mengorganisasikan informasi, menciptakan nama konsep dan dalam melakukan pengetesan hipotesis yang melukiskan antara hal. Pada strategi pembelajaran induktif dimulai dengan memberikan bermacam-macam contoh, dan dari contoh-contoh itu siswa membahas 
materi dengan memberikan bermacam-macam contoh lagi. Kemudian dari contoh-contoh itu, siswa mengerti keteraturan dan mengambil keputusan yang bersifat umum. Pendekatan induktif adalah suatu strategi yang direncanakan untuk membantu siswa mengembangkan kemampuan berpikir tingkat tinggi dan kreatif melalui observasi membandingkan, penemuan pola, dan menggeneralisasikan. Guru mendorong siswa mengadakan pengamatan dan memfokuskan pengamatan melalui pertanyaanpertanyaan, dan siswa yang harus lebih aktif. Sedangkan pada pembelajaran deduktif tidak menekankan pada upaya menciptakan dan mengkontruksi pengetahuan secara aktif. Namun pembelajaran deduktif lebih menekankan pada pendidik dalam menyampaikan pembelajaran sehingga peserta didik cenderung pasif untuk mengikuti presentasi dan penjelasan tentang konsep, teori, prinsip, dan prosedur pelaksanaan kemudian melakukan imitasi berdasarkan contoh yang telah diberikan oleh guru (Anon, 2012:4). Jadi untuk proses pembelajaran konsep dasar ekologi, lebih baik menggunakan strategi pembelajaran induktif dari pada strategi pembelajaran deduktif. Hipotesis 2, Bagi kelompok siswa yang memiliki self-efficacy tinggi, untuk pengetahuan konsep dasar ekologi yang diajar dengan strategi pembelajaran induktif lebih tinggi, jika dibandingkan yang diajar dengan strategi pembelajaran deduktif. Hasil penelitian (Qhit. 4,961 > Qtab. $(\alpha=0,05 ; \mathrm{db} 1=4 ; \mathrm{db} 2=10) 4,26)$ bahwa bagi kelompok siswa yang sama-sama memiliki self-efficacy tinggi, untuk kelompok siswa yang diajar dengan strategi pembelajaran induktif lebih baik, dari pada kelompok siswa yang 
diajar strategi pembelajaran deduktif, terhadap pengetahuan tentang konsep dasar ekologi. Hasil penelitian ini juga menunjukkan skor rata-rata yang diperoleh masing-masing kelompok siswa yang sama-sama memiliki selfefficacy tinggi, yang mengikuti strategi pembelajaran induktif memperoleh skor rata-rata 50,667 berarti setiap siswa yang memiliki self-efficacy tinggi yang mengikuti strategi pembelajaran induktif dapat mengetahui materi konsep dasar ekologi sebesar 50,667 (83,06\%) dari skor maksimum sebesar 61. Sedangkan yang mengikuti strategi pembelajaran deduktif memperoleh skor rata-rata 44,917 berarti setiap siswa yang memiliki self efficacy tinggi yang mengikuti strategi pembelajaran deduktif dapat mengetahui materi konsep dasar ekologi sebesar 44,917 (73,63\%) dari skor maksimum sebesar 61. Nyata pada temuan penelitian ini bahwa bagi kelompok siswa yang memiliki self-efficacy tinggi diajar strategi pembelajaran induktif dapat mengetahui materi konsep dasar ekologi lebih baik dari pada kelompok siswa yang juga memiliki self-efficacy tinggi diajar dengan strategi pembelajaran deduktif. Jadi untuk pembelajaran materi konsep dasar ekologi lebih baik menggunakan strategi pembelajaran induktif dari pada strategi pembelajaran deduktif pada kelompok siswa yang memiliki self-efficacy tinggi. Hipotessis 3, Bagi kelompok siswa yang memiliki self-efficacy rendah, untuk pengetahuan konsep dasar ekologi yang diajar dengan strategi pembelajaran deduktif lebih tinggi, jika dibandingkan yang diajar dengan strategi pembelajaran induktif. Hasil penelitian (Qhit. -

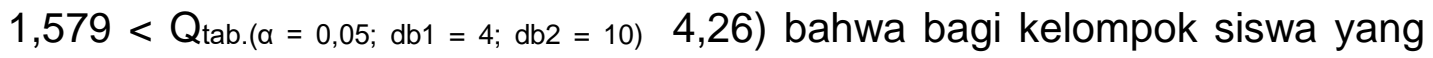
sama-sama memiliki self-efficacy rendah, untuk pengetahuan tentang 
konsep dasar ekologi yang diajar strategi pembelajaran deduktif lebih baik, dari pada yang diajar strategi pembelajaran induktif. Temuan ini berarti tinggi rendahnya self-efficacy yang dimiliki siswa dan juga penerapan strategi pembelajaran dalam proses pembelajaran, tidak terlalu berkotribusi positif terhadap pengetahuan siswa tentang konsep dasar ekologi. Hasil penelitian ini juga menunjukkan skor rata-rata yang diperoleh masing-masing kelompok siswa yang sama-sama memiliki self-efficacy rendah, yang mengikuti proses pembelajaran dengan penerapan strategi pembelajaran induktif memperoleh skor rata-rata hanya 44,50 berarti setiap siswa yang memiliki self-efficacy rendah yang mengikuti proses pembelajaran dengan strategi pembelajaran induktif hanya dapat mengetahui materi konsep dasar ekologi sebesar 44,50 (72,92\%) dari skor maksimum sebesar 61 . Sedangkan kelompok siswa yang mengikuti proses pembelajaran dengan penerapan strategi pembelajaran deduktif memperoleh skor rata-rata 46,333 berarti setiap siswa yang mengikuti proses pembelajaran dengan penerapan strategi pembelajaran deduktif dapat mengetahui materi konsep dasar ekologi sebesar 46,333 (75,96\%) dari skor maksimum sebesar 61 . Apabila penyebab hasil tersebut dikaji, maka dapat dikatakan bahwa yang mendasari pengetahuan siswa tentang konsep dasar ekologi adalah lemah, sehingga untuk mengetahui tentang konsep dasar ekologi adalah juga menjadi rendah. Sehubungan dengan hal self-efficacy yang dimiliki siswa yang seharusnya dapat membantu menguatkan pengetahuan tentang konsep dasar ekologi yang rendah, maka strategi pembelajaran tidak berpengaruh banyak terhadap pengetahuan siswa tentang konsep dasar 
ekologi. Oleh karena itu, bagi kelompok siswa yang memiliki self-efficacy rendah lebih baik diajar strategi pembelajaran deduktif, dari pada diajar strategi pembelajaran intuktif. Hipotesis 4, Terdapat pengaruh interaksi antara strategi pembelajaran dan self-efficacy terhadap pengetahuan siswa tentang konsep dasar ekologi. Hasil penelitian $\left(F_{\text {hit. }} 10,70>F_{\text {tab. }(0,05 ; 1 ; 47)}\right.$ 4,06) bahwa secara bersama-sama strategi pembelajaran dan self-efficacy berkontribusi positif terhadap pengetahuan siswa tentang konsep dasar ekologi. Temuan ini dapat dijelaskan bahwa pada satu segi strategi pembelajaran memberi kesempatan kepada siswa untuk mengetahui tentang konsep dasar ekologi secara kolaboratif, namun di lain segi selfefficacy memberikan keyakinan kuat bagi siswa untuk pengetahui tentang konsep dasar ekologi. Jadi baik pengalaman belajar karena perlakuan penerapan strategi pembelajaran, maupun self-efficacy yang dimiliki secara bersama-sama memberi pengaruh positif terhadap pengetahuan siswa tentang konsep dasar ekologi. Pengaruh Interaksi antara strategi pembelajaran dan self-efficacy terhadap pengetahuan siswa tentang konsep dasar ekologi Nampak pula pada perolehan skor rata-rata 46,542 dari keseluruhan siswa, berarti setiap siswa dapat mengetahui materi konsep dasar ekologi rata-rata sebesar $46,542(76,30 \%)$ dari skor maksimun sebesar 61. Dalam hal ini siswa mencapai hasil pengetahuan tentang konsep dasar ekologi karena mendapat kontribusi pengaruh dari strategi pemelajaran yang diikuti dan self-efficacy yang dimiliki. 


\section{KESIMPULAN}

Secara keseluruhan, pengetahuan tentang konsep dasar ekologi pada kelompok siswa yang diajar strategi pembelajaran induktif lebih baik, dibandingkan yang diajar strategi pembelajaran deduktif. Artinya terdapat perbedaan pengetahuan siswa tentang konsep dasar ekologi, karena adanya pengaruh strategi pengelajaran induktif yang lebih baik dari pada strategi pembelajaran deduktif dalam proses pembelajaran.

Bagi kelompok siswa yang memiliki self-efficacy tinggi, untuk pengetahuan tentang konsep dasar ekologi yang diajar strategi pembelajaran induktif lebih baik, dibandingkan yang diajar strategi pembelajaran deduktif. Artinya terdapat perbedaan pengetahuan tentang konsep dasar ekologi bagi kelompok siwa yang memiliki self-efficacy tinggi, karena adanya pengaruh strategi pembelajaran induktif lebih baik dari pada strategi pembelajaran deduktif dalam proses pembelajaran.

Bagi kelompok siswa yang memiliki self-efficacy rendah, untuk pengetahuan konsep dasar ekologi yang diajar strategi pembelajaran deduktif lebih baik, dibandingkan yang diajar strategi pembelajaran induktif. Artinya terdapat perbedaan pengetahuan tentang konsep dasar ekologi bagi kelompok siwa yang memiliki self-efficacy rendah, karena adanya pengaruh strategi pembelajaran deduktif lebih baik dari pada strategi pembelajaran induktif dalam proses pembelajaran.

Terdapat pengaruh interaksi antara strategi pembelajaran dan self-efficacy terhadap pengetahuan siswa tentang konsep dasar ekologi. Artinya terdapat 
perbedaan pengetahuan siswa tentang konsep dasar ekologi, karena adanya pengaruh secara bersama-sama strategi pembelajaran dalam proses pembelajaran dan self-efficacy yang dimiliki siswa.

\section{DAFTAR PUSTAKA}

Anon. "Pembelajaran Deduktif-Induktif dna Upayah Pemecahannya," http://www. kampussaya.com/2010/pembelajaran-deduktif-induktif-da-upayapemecahannya, (diakses Oktober 2010).

Anon. "Strategi Pembelajaran Dedutif dan Induktif", tugasqnghjj.blogspot.com/ .../strategi-pembelajaran deduktif-induktif (diakses 19 Juni 2012).

Borg, Walter D. and Meredith D. Gall, 1983 Educational Research, an Inroduction, $4^{\text {th }}$ Ed. New York: Longman Inc.

Bandura, Albert, 1997 Sel-Efficacy: The Exercise of Control. (New York: W.H. Freeman.

Bruce, Jouse, 2000, Models of Teaching, $6^{\text {th }}$ Edition. London: Allyn \& Bacon. Gagne, Robert M. and Lestie J. Briggs, 1979, Principles of Instructional, 2 th Edition. Florida: Holt, Rinehart and Winston.

Irwan, 2010, Zoer'aini Djamal. Prinsip-Prinsip Ekologi: Ekosistem, Lingkungan, dan Pelestariannya. Jakarta: Bumi Aksara.

Lennon, Jean M, 2010, Self-Efficacy dalam Noncognitive Skills in $t$ he Classroom: New Perspectives on Educational Research, (Eds.) Jeffry A. Rosen et al. Triangle Park: Research Triangle Institute. Nitko, Anthony J, 1996, Educational Assesment of Students. Ed. $2^{\text {nd }}$ Engelwood Cliffs: Prentise Hall. 
Odum, Eugene P, 1971 Fundamentals of Ecology. Philadelphia: W. B. Saunders Company. , 1979 Fundamental of Ecology, Third Edition. Georgia: Sourders College Publishing.

Odum, Eugene P. dan Gery W. Barrett, 2005 Fundamentals of Ecology, Australia: Thomson Brooks/Cole.

UNESCO, 1977, Trenin Environmental Education. Paris: United Nation Education, Scientific and Culture Organization. 